\title{
General Commentary: Federal Labour Court [2009] - 8 AZR 1012/08
}

\author{
Kyriakos N. Kotsoglou* \\ Law Department, Liverpool Hope University, Liverpool, UK
}

Keywords: evidence and proof, law of evidence, labour law, forensic sciences, reference class problem

A commentary on

Federal labour court [2009] - 8 AZR 1012/08

For Silke K., it must have been one of these days that define someone's story beyond her life. After years of suffering gender discrimination and mobbing at work, the Berlin-Brandenburg's Labour Court (LAG) had just issued a game-changing decision in her favor. The question before the court essentially boiled down to whether the claimant had discharged her burden of proof simply by employing formal statistical methods. LAG's answer was positive. It awarded damages that included the difference $(€ 1.468)$ between Silke K.'s monthly salary and a director's one, damages for sex discrimination $(€ 28.214,66)$, and damages for violating rights of personality $(€ 20.000)$ (Second Instance Land Labour Court, 2008).

The decision did not only implement the new policy enshrined in the General Equal Treatment Act 2006 (Allgemeines Gleichbehandlungsgesetz) - whose purpose was to put an end to discrimination against vulnerable social groups of workers and vertical segregation in labor market creating steep asymmetries between the percentage of women in higher positions and the total labor force (ILO Director-General, 2011) - but also most importantly constituted a paradigm shift regarding the legal protection of female employees. More specifically, whereas women were making up at that time the majority (69\%) of the defendant's workforce (Second Instance Land Labour Court, 2008, para 23), not a single one of them was in the board of directors (Second Instance Land Labour Court, 2008, para 14), exemplifying thus in a clear way that women are "widely underrepresented" in decision-making positions in the private sector of Germany (EU Document of the Directorate General for Internal Policies, 2015). But what exactly propelled this long expected success and engineered the closing of the persistent gender pay gap?' ${ }^{1}$ Silke K.s team of lawyers had hired a mathematician to calculate the probability that it is not random that the board of directors includes no women. The probability, the statistical analysis (Monte-Carlo simulation) showed, was between 98.7\% and 100\% (Second Instance Land Labour Court, 2008, para 34). Therefore, it was formal statistical calculations that gave thrust to the gender equality machinery, since the LAG explicitly equated this statistical result with the probability of discrimination against the claimant (Second Instance Land Labour Court, 2008). By employing a rigorous framework to draw inferences from data, courts broke the "glass ceiling", i.e., the "unseen, yet unbreakable barrier that keeps minorities and women from rising to the upper rungs of the corporate ladder, regardless of their qualifications or achievements" (Federal Glass Ceiling Commission, 1995).

Alas all good things come to an end. The Federal Labour Court (BAG) quashed the decision as it held that statistics are not conclusive for the individual case (Federal Labour Court [2009]). Although there was no explicit mention of the reference class problem in the decision, the Federal Court raised once again questions of sufficiency of proof by making clear that proof of unlawful behavior hinges

\footnotetext{
${ }^{1}$ According to the EU report (EU Document of the Directorate General for Internal Policies, 2015, p. 15): "In general, Germany is ranked by the European Gender Equality Index (GEI) lower than the EU average; its performance in achieving gender equality is 'mediocre."
} 
on "statistical data being conclusive for the employer in question", to wit, on specific evidence (Federal Labour Court [2009], para 68): proof of membership to a reference group is inconclusive.

This brings us to our main issue, the meaning of "specific evidence" and the renowned reference class problem (Colyvan et al., 2001). Can statistical information-accurate as they may be-motivate action? The question is at its kernel whether an epistemic inference from a relevant population-which serves as a basis for calculating and assigning probabilities-to an individual is valid-given that we only have information about the reference class. Since we deal with the problem of factual generalization and individualization, we rather unwillingly have to raise fundamental questions about the nature of our reasoning processes, in both law and elsewhere. Unsurprisingly, these issues have spawned an extensive debate Allen and Roberts (2007). For very good reasons, since legal adjudication aspires to be rational. However, there is no consensus on what lessons to draw. The debate between the opposing parties has stalled. It would not be exaggerating to say that we have reached the point "where one would like just to emit an inarticulate sound" (Wittgenstein, 1958, $\$ 261)$.

This short commentary suggests that we should not be so pessimistic. From Aristotle who observes that "it is evidently equally foolish to [...] demand from a rhetorician scientific proofs" (Aristotle, The Nicomachean Ethics, Book I, Ch. 3) to modern forensic scientists who are at pains to stress that the idea "of a frequency being attached to an outcome for a single event is ridiculous" (Lucy, 2006, 5), scholars have continuously rejected

\section{REFERENCES}

Allen, R., and Roberts, P. (eds). (2007). The special issue on the reference class problem. Int. J. Evidence Proof 11, 243-317.

Aristotle. The Nicomachean Ethics, Book I: The Good for Man, Chap. 3.

Colyvan, M., Regan, H. M., and Ferson, S. (2001). Is it a crime to belong to a reference class? J. Political Philos. 9, 168-181; discussion 171. doi:10.1111/ 1467-9760.00123

EU Document of the Directorate General for Internal Policies. (2015). The Policy on Gender Equality in Germany. 8. Available at: http://www.europarl.europa. eu/studies

Federal Glass Ceiling Commission. (1995). Solid Investments: Making Full Use of the Nation's Human Capital. Washington, DC: US Department of Labor, 13-15. Federal Labour Court [2009] - 8 AZR 705/08.

ILO Director-General. (2011). Equality at Work: The Continuing Challenge. Report I(B). Geneva: International Labour Conference 100th Session. (bogus) aspirations of generality when it comes to (judicial) decisions. True, statistics enable us to validate knowledge-claims about the world; but at the same time, we resort to quantitative evidence in order to gain an understanding of a population in its entirety. This simple expression-“in its entirety"-destroys the riddle. Courts and decision makers do not formulate general rules. They give answers to questions such as "Is the defendant guilty?" to which we do not have scientific answers, not because they are intractable, profound mysteries, but simply because decision-making is not a scientific process yielding a generally valid solution. Of course, statistics should inform the evidential basis of decisions and help settle arguments. However, judges do have discretion when they apply the law, so that we have to willynilly reject the idea(l) of a mechanical jurisprudence. Extending statistical ideas and methods to procedural and forensic contexts can broadly be classified as scientism.

The Federal Labour Court made a move in the right direction. It criticized the transgression of the bound of "specific evidence" and reaffirmed the individualistic character of legal adjudication by authoritatively cutting the Gordian knot (reference class problem). The academic community has to deliver ex post facto the theoretical framework that (dis-)solves this problem.

\section{AUTHOR CONTRIBUTIONS}

The author confirms being the sole contributor of this work and approved it for publication.

Lucy, D. (2006). Introduction to Statistics for Forensic Scientists. New York: Wiley.

Second Instance Land Labour Court. Berlin-Brandenburg [26.11.2008] - 15 Sa 517/08; NZA 2009, 43.

Wittgenstein, L. (1958). Philosophical Investigations. Oxford: Basil Blackwell, § 261.

Conflict of Interest Statement: The author declares that the research was conducted in the absence of any commercial or financial relationships that could be construed as a potential conflict of interest.

Copyright (c) 2017 Kotsoglou. This is an open-access article distributed under the terms of the Creative Commons Attribution License (CC BY). The use, distribution or reproduction in other forums is permitted, provided the original author(s) or licensor are credited and that the original publication in this journal is cited, in accordance with accepted academic practice. No use, distribution or reproduction is permitted which does not comply with these terms. 